\title{
The Cultivation of Talents in Application-Oriented Universities in the Context of New Engineering
}

\author{
Xing-liu HU*, Hai-fei SI, Zhong YANG and Nan XU \\ College of Intelligent Science and Control Engineering, Jinling Institute of Technology, Nanjing, \\ China \\ ${ }^{*}$ Corresponding author
}

Keywords: Applied talents, Innovation, Applied talents training mode, Developed countries.

\begin{abstract}
The development of new economy challenges the cultivation of engineering talents. Application-oriented engineering talents of the new economy should have the characteristics of cross-disciplinary and cross-industry integration. All these require engineering talents to construct the thinking mode that meets the new economic requirements, and have the consciousness and ability to innovate and start a business. New economy and the demand for talents provides an opportunity for the new engineering.
\end{abstract}

\section{Introduction}

At present, a new technological revolution and industrial transformation is accelerating in the world, and the competition of comprehensive national strength is becoming increasingly fierce. The nature of the new century's competition and development is the competition for qualified personnel and further development of quality, which, in the final analysis, lies in educational competition and development. Countries all over the world are competing to focus on education competitiveness, and they have developed plans for education development, highlighting education as a preparation for future development. In 2016, a concept of 'new engineering' is put forward to, which has formed the 'fudan consensus' and 'tiantai operation' successively. At the same time, in order to implement the 'talent cultivation' strategic plan further, the 'national medium and long-term education reform and development plan is formulated which is called outline (2010-2020)', the outline is to emphasize cultivating all kinds of talents, especially 'applied' talents, the talents development plan highlights the application talents for national construction and economic development.

There is the world's largest engineering education in our country, according to the data from education department. In 2016, there are 5.21 million of engineering undergraduate students, 1.19 million of college graduates in our country. The number of the distribution of specialties is 17037, engineering students accounted for about a third of the total number of high education students. In contrast to the large engineering students, the employment situation of college graduates is grim, and the dilemma between college students' employment and employment difficulties has not been effectively alleviated. There are several reasons for the outstanding structural contradiction of talent demand in China: students' professional ability is low, which is not consistent with the requirements of employers. Our talent training mechanism and professional setting are unreasonable, the course content cannot meet the needs of the society, and the cultivated students' practical ability is deficient. The manufacturing talent development planning guidance is established by the ministry of education and the ministry of industry, which points out that personnel training is irrelevant to the actual needs of the manufacturing businesses, the integration between the education and the industry is not enough, engineering education practice is weak, the foundation construction of schools and training institutions is lagged.

Local colleges and universities are the largest proportion in the whole system of education, which is an important force for promoting regional economic and social development. The important mission of serving local economic and social development is undertook by the local colleges and universities. We should improve the personnel training mode of 'applied' local universities and 
colleges 'undergraduate course, catch up with international advanced intelligent manufacturing. We should also response to a national strategic needs, support the new economy development which is supported by new technology, new forms, new industries and new patterns. Cultivating high quality applied talents which meet the regional economic and social development needs is a looming problem which is faced by all applied colleges and universities.

\section{The Current Cultivation Situation of Application- Oriented Undergraduate Talents Abroad}

The cultivation of applied talents in foreign universities is mainly developed in the 1960s. After decades of practice, developed countries such as the United States, Britain, France and other developed countries have developed a more mature model of application-oriented talent cultivation.

\section{Applied Talents Cultivation in the United States}

The cooperative training mode is adopted in some universities of the United States to cultivate applied talents. Currently, many large enterprises cannot find suitable graduates in the United States, so the enterprises' managers actively cooperate with colleges and universities to cultivate the talents they needed. In this process, the cooperation institutions with universities undertake the tasks such as internship, training, practice and practical teaching, aiming at improving students' ability of application ability to meet enterprise standards ${ }^{[1]}$.

Universities and colleges in the United States is in the form of the school and syndication advisory group or held a meeting to discuss their concerns. Enterprises give corporate loans and financing for university students scholarship. Colleges and universities can share the equipment with enterprises, cooperate in scientific research and technology development. Colleges and universities can participate in the activities of enterprise training, help enterprise courses training employees.

\section{Applied Talents Cultivation in England}

British universities adopt 'sandwich' courses in the curriculum, the so-called ' $2+1+1$ ' mode which means students learning basic theory knowledge at school in the first two years, taking an internship in this company in the third year, returning to the university to study in the fourth year ${ }^{[2]}$. After one year of working experience, the students who return to the university will be more specific about the purpose of study and the application of theoretical knowledge.

The British universities establish a partnership with enterprises to carry out various forms of cooperation, such as enterprises certification courses and enterprises scholarships. Enterprises are involved in curriculum design, learning resources and research projects, they also provide practice base, and send enterprise senior staff tutoring students and so on. Among them, the industry certification course is one of the major features of the UK applied talent production, which mainly includes the three forms of well-known enterprise certification courses, corporate degree courses and industry association certification courses.

\section{Applied Talents Cultivation in in France}

French colleges and universities regard the cultivation and training of students' practical ability and innovative quality as the core of the training mode. The Ecole Centrale Paris is a representative of the professionals training mode, the college students which are in first and second grades is to learn basic knowledge in science and engineering, regardless of major, The aim of this is to cultivate students to get solid academic foundation. Two years later, according to the students' interest and academic status, the professional field should be divided to promote the improvement of students' innovation ability and comprehensive quality ${ }^{[3]}$.

\section{Applied Talents Cultivation in Japan}

Japan colleges' method is to combine the general education with professional education in undergraduate education. They strengthen the liberal arts courses and pay attention to the 
cultivation of students' innovative ability. They change the situation of cultivating students who lack independent and creative ability. In curriculum, some comprehensive subjects of general education and professional education phase also appeared ${ }^{[4,5]}$. By 2003, the national university of Japan, credits of comprehensive subjects has accounted for $5.87 \%$ of the total credits of undergraduate course education stage. Some universities even have interdisciplinary education and interdisciplinary research which combines literature, science and engineering.

In 2001, in order to cultivate the advanced comprehensive talent with broad vision. Osaka University, established the intersecting life sciences graduate school in the field of discipline and broke the present situation that the graduate school was divided into medical, science, engineering and so on.

\section{Current Situation of Domestic Application-Oriented Undergraduate Talents Training}

Comparing with developed countries, the talent cultivation model reform of China's higher education generally starts late and has a slow pace. Due to the influence of the management system and operational mechanism, local colleges has shortcomings comparing with '985', '211' and other key universities, in various aspects such as courses, practice teaching, universal existence big difference, education teaching reform, especially the talent training mode reform. There are a lot of problems in talents training.

\section{The Target of Application-Oriented Personnel Training not Clearly Defined}

In the training process of applied talents in colleges and universities, they pursue the training goal blindly for great perfection and they don't combine the scale of applied talents training with the school's own ability .They think that the more number of applied talent training, the better benefit to the universities. There is no close combination of the characteristics of the school, so we blindly add new subjects and majors. In addition, it is also a case of blind upgrading and high level of research-oriented pursuit. The type of the target of application-oriented talent cultivation is prominent. Due to the old concept of higher education and the allocation of resources such as policy, the applied undergraduate colleges tend to have narrow positioning, high positioning and featureless positioning.

\section{Some Limitations in the Curriculum Setting of Application-Oriented Undergraduate Institutions}

There are generally similar courses, which are lack of creativity and enlightening, and narrow the scope of knowledge. The practice teaching link is weak, the effect is very little. The unreasonable curriculum system will directly affect the quality of teaching, thus reduce the competitiveness of college graduates' employment.

\section{Few Contacts between the Applied Undergraduate Institutions and the Business Community}

Some colleges and universities develop their own talent training objectives, design talent training programs, implement personnel training process and evaluate talent training results without communicating with social enterprises, which leads to the result that the quality of talent training in colleges and universities cannot meet the needs of employers.The joint cultivation of school-enterprise is not extended to the actual stage of student training.

\section{Insufficient Practice Teaching Resources and Practice Training Base Construction}

The lack of practical teaching resources is another important factor that restricts the cultivation of undergraduate application-oriented talents in universities. Along with the popularization of higher education, the local university student scale is increasing. The practice teaching resources include the school laboratory and off-campus practice bases construction did not keep up with the student enrollment expansion speed. This affect the cultivation of the students' practical ability. On the other hand, local colleges and universities pay little attention to practical teaching and the practice 
teaching system is not perfect. Practical training sometimes fails to be practical, and the cultivation of students' practical ability is not optimistic.

\section{The Ability Demand of Applied Undergraduate Talents under the New Economic Conditions}

\section{Adapting to Different Social Needs}

Engineering education is closely linked and supported by industry development. Engineering education is the fundamental characteristic of cultivating talents for social production activities. The key point of new engineering construction is to define the industrial demand and promote the reform and innovation of existing talent cultivation. Some needs, such as the job market, services, service positions and requirement for talents is not the same. If all be taught the same, it is difficult to foster qualified talents for meeting the demand of society and the enterprise, especially local application of colleges and universities. In the process of education, local colleges and universities should consider the development of local regional economy and develop talents according to local regional market.

\section{Cross-Boundary Integration Capability}

Based on the science of the new economy, the group technology revolution with green, intelligent and ubiquitous features is of typical characteristic which is interdisciplinary integration. Natural and social phenomenon is a complex system, it is difficult to reveal the nature of its laws from a single point of view or level, and it is impossible to know the whole law profoundly. Only from the multi-perspective and multi-level, can the complete and systematic understanding be formed. The discipline is a relatively independent knowledge system, and the economy will give birth to a number of new disciplines with cross-boundary characteristics. Therefore, application-oriented engineering talents of the new economy should have the characteristics of cross-disciplinary and cross-industry integration.

\section{Good Humanistic Quality}

At the same time, the new economy is a sustainable economy. The economic essence of sustainable development is 'people-oriented' economy. The 'people-oriented' economy requires the development of economic growth and social development while focusing on human development. Qualified college students not only need to have solid professional quality, but also need to have a good humanistic quality, so as to provide the special power and intellectual support for the rational and healthy development of the new economy.

\section{Innovation and Entrepreneurship Awareness and Ability}

The essence of the new economic development is the reconfiguration of factor resources and the reconstruction of production relations, and the key lies in innovation. All these require engineering talents to construct the thinking mode that meets the new economic requirements, and have the consciousness and ability to innovate and start a business. The new economic environment presents new requirements and challenges for participants, and new requirements and challenges need to be completed by talents. Only by strengthening the cultivation of innovative talents can we realize the transformation of China's development from dependence on material resources to the development of science and technology and human capital.

\section{Conclusion}

New economy new target and the demand for talents provides an opportunity for the new engineering.The goal of talent cultivation of applied colleges is to cultivate who can adapt to the, and even lead the future demand. Compared with traditional engineering talents, new engineering talents with high quality are needed by the future new industries and new economy, who are of engineering practice ability and innovation ability, and can understand the technical and economic, 
social, management integration.

New requirements of talents under the new economic conditions should be emphasized by local application-oriented colleges and universities. They should promote the innovation of talent cultivation mode, realize students professional skills, application ability and professional demand, promote the similar subjects infiltration. In order to meet the demand of industry and regional economic development needs of applied, skilled, compound talents, they should also strengthen students' practical innovation ability and train practical engineering.

\section{Acknowledgement}

This research was financially supported by the National Science Foundation. This work was supported by the Ministry of Education's Cooperative Education Project (No:201701056001), Jinling Institute of Technology's Education Reform Project (No.2017JYJG03),National Science Foundation of the Higher Education Institutions of Jiangsu Province (No.15KJB520010), Qing Lan Project, Jiangsu Province's Natural Science Foundation （No.BK20171114）,A joint prospective industry-University-Research Collaboration project of Jiangsu Province (No.BY2016012-02), Jinling Institute of Technology’s Research Training Project (No.Jit-fhxm-201606).

\section{References}

[1] Augustine, Norman R. "Rising above the gathering storm: Energizing and employing America for a brighter economic future." Retrieved March 19 (2005): 2008.

[2] Bao, F., \& Wang, Y. A Study on Digital Media Talent Cultivation Model of British Higher Institutions and its Inspiration. Studies in Foreign Education, 38(258), 44-49. (2011)

[3] YANG, C. C., \& LIU, J. P. A Comparative Study on Talent Cultivation Modes of Application-oriented Undergraduate Education in China and Foreign Countries [J]. Journal of Nanjing Institute of Technology (Social Science Edition), 3, 006. (2007)

[4] Weiliang, C. Some thoughts on foreign language talent cultivation [J]. Foreign Language World, 6, 008. (2009)

[5] Haijing, Y. Comparison of Corporation of Enterprising and Learning and Talent Cultivation Models of Higher Vocational Education in the US, Germany, Japan and Australia [J]. Vocational and Technical Education, 2, 031. (2006) 